\title{
SPECIALIZED HERBIVORY ON INFLORESCENCE STALKS OF TRICHOCENTRUM UNDULATUM (ORCHIDACEAE) BY MELANAGROMYZA SP. (DIPTERA: AGROMYZIDAE) IN CUBA
}

\author{
Haydee Borrero ${ }^{1,2}$, Julio C. Alvarez ${ }^{3}$, Ramona O. Prieto ${ }^{3} \&$ Hong Liu $^{1,2,4}$ \\ ${ }^{1}$ Florida International University, Department of Earth and Environment \\ and International Center for Tropical Botany, Miami, 33199, U.S.A. \\ ${ }^{2}$ Fairchild Tropical Botanic Garden, Coral Gables, 33156, U.S.A. \\ ${ }^{3}$ The Institute of Ecology and Systematics, National Herbarium “Onaney Muñiz”, Havana, Cuba \\ ${ }^{4}$ Corresponding author: hliu@fiu.edu
}

\begin{abstract}
Inflorescence stalk herbivory on the Mule Ear orchid (Trichocentrum undulatum) has been observed in Cuba, which resembles the specialized herbivory interaction seen in southern Florida between a specialized dipteran, Melanagromyza miamensis (Agromyzidae) and the Mule Ear orchid. We are able to identify the inflorescence herbivore to be the genus Melanagromyza. It is possibly the same species that can be found in southern Florida. The mule-ear orchid is endemic to the Caribbean region, i.e. Cuba, Jamaica and southern Florida. To our knowledge, this is the first report of an apparently specialized inflorescence stalk herbivory by Agromyzid flies on the Mule Ear orchid in Cuba. The herbivory can partially or completely destroy the flowering potential of the impacted plants.
\end{abstract}

KeY worDs: Agromizid, Cape-sable orchid, Florida endangered orchid, Oncidiinae, orchid herbivory

Introduction. Trichocentrum undulatum (Sw.) Ackerman \& M.W.Chase is an epiphytic orchid whose distribution extends from Jamaica, Cuba and Bahamas to Florida (Ackerman 2014). The population in southern Florida is the northernmost limit of the species and is the only mainland North American population. In southern Florida, T. undulatum is rare and only found in a restricted area of coastal salt marsh found growing only on buttonwood trees (Conocarpus erectus L.). This Florida population is subject to specialized inflorescence stalk herbivory by Melanagromyza miamensis Spencer. Such herbivory has not previously been reported beyond southern Florida (Higgins \& Gann 2007, Seavey \& Seavey 2018, Spencer \& Stegmaier 1973).

The dipteran genus Melanagromyza (Agromyzidae) consists of over 300 species and is distributed worldwide (Spencer \& Steyskal 1986). Not much is known about host plants used by the majority of Agromyzids due to the difficulties in capturing or rearing adult flies or difficulties with locating puparia within plant tissues (Spencer 1990). Herein we report inflorescence stalk herbivory of $T$. undulatum observed in four provinces within Cuba (Artemisa, Cienfuegos, Matanzas, and Sancti Spiritus).

Methodology. Trichocentrum undulatum can be found within every province of Cuba, in different habitats, and growing on a diversity of phorophyte hosts. Four populations of T. undulatum were visited in Cuba in the provinces of Artemisa, Cienfuegos, Matanzas, and Sancti Spiritus during the summers of 2016 and 2017. Transects were laid out within forest stands where the orchid was known to grow. A total of four transects were made at four wild populations in the Artemisa (one transect) and Matanzas (three transects) provinces. Inflorescence stalks were also evaluated and collected for herbivore presence at Macradenia Orchid Garden in Cienfuegos province and Comunidad 23 Orchid Garden in Sancti Spiritus province. For every T. undulatum plant encountered on the transect, a search for other plants was made within a five-meter radius. The length of the transects varied between 20 to 100 meters, depending on the forest 
size and habitat topography. Inflorescence stalks were collected from every individual that had flowered in February/March (the flowering season for the species) and had failed to produce fruit. The inflorescence stalks were labelled and later dissected to determine the presence of an inflorescence stalk herbivore. Exit holes were examined and any pupal casings found were photographed.

Results. Although no adult fly exiting T. undulatum was captured, larval casing characteristics were used to determine that the herbivores affecting inflorescences of $T$. undulatum within Cuba are a Melanagromyza species. Pupal casings were extracted from inflorescence stalks from all of the transects sampled. The larvae found in the orchid samples fitted the description of the genus Melanagromyza by having two sclerotized plates with pronounced "bulbs" atop the plates with a protruding "horn" in the center (Fig. 1) (Spencer \& Steyskal 1986). This identification had also been confirmed by an Agromyzidae specialist (Scheffer pers. comm. 2017). Exit holes found on the inflorescence stalks were similar to those found in the southern Florida population (Fig. 2). No other Diptera larvae were found within the flowering stalks, leaves, or fruits of T. undulatum.

A total of 391 plants were located in the transects between the 2016 and 2017 surveys. Of these, 149 $(38 \%)$ produced inflorescences. The percentage of sampled flowering plants with Melanagromyza sp. presence was $48 \%$ (72 plants). The number of inflorescences produced by a plant generally varied between one to six stalks between the two surveys. A total of 198 inflorescence stalks were collected and examined. Of these, 87 inflorescences (44\%) exhibited dipteran casing presence.

Despite approximately half of all flowering plants having been attacked by Melanagromyza sp., we observed fruit in both 2016 (two fruit out of 85 flowering plants) and 2017 (one fruit out of 64 flowering plants) (Fig. 3). Vouchers of the puparia casings and the inflorescence stalk tips exhibiting exit holes and boring architecture were deposited at the Onaney Muñiz National Herbarium from the Institute of Ecology and Systematics, Havana, Cuba.

Discussion. Our study is the first to report the presence of inflorescence herbivory of $T$. undulatum by an

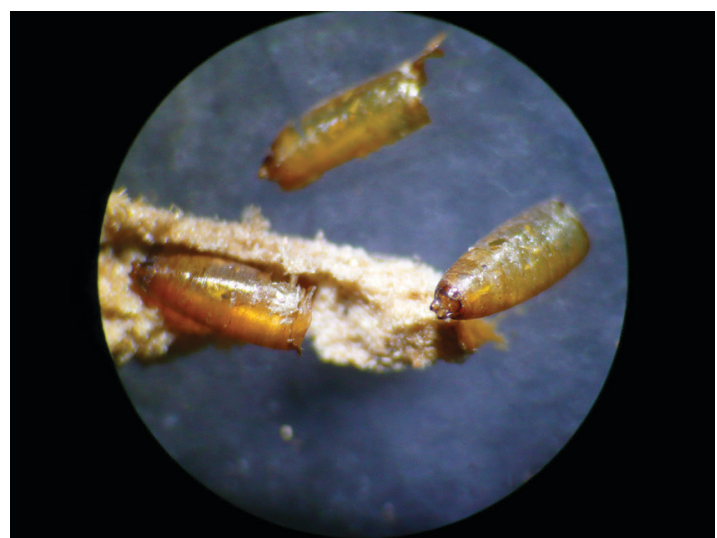

FiguRe 1. Pupal casings of a Melanagromyza sp. found within an inflorescence stalk in Cuba, summer 2016. The sclerotized plate with the doubled "horns" are apparent and particular for the genus.

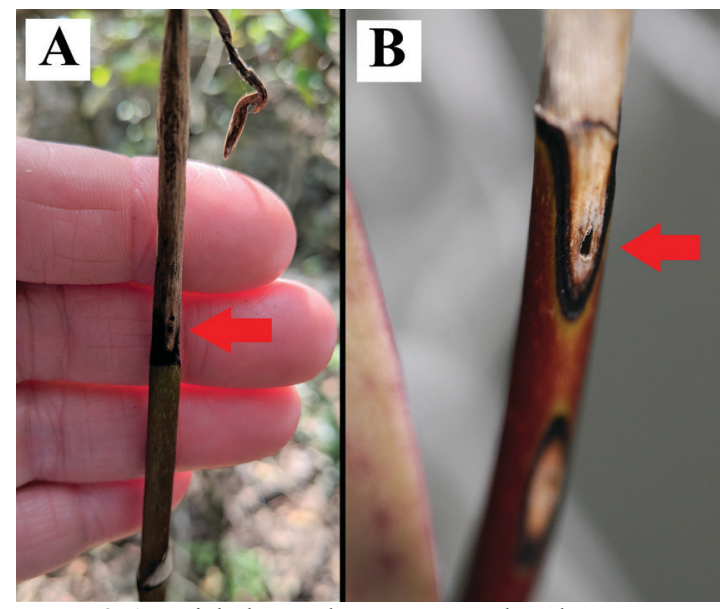

FigURE 2. A. Exit holes made to accommodate the emergence of adult dipteran(s) from infested inflorescence stalks of Trichocentrum undulatum in Matanzas province, Cuba 2016. B. Exit holes made from emerging adult Melanagromyza miamensis from a $T$. undulatum inflorescence stalk in Florida, USA, 2013.

Agromyzid fly in Cuba. Due to the host specialization nature of the Agromyzidae family (Spencer 1990), it is possible that the observed Melanagromyza in Cuba is the same species as that found in southern Florida, but this requires further taxonomical study by a specialist. Melanagromyza sp. has only been observed in the inflorescence stalks of T. undulatum and not on any other orchid species in the surrounding areas assessed in Cuba and southern Florida (Borrero unpubl. 2017). In southern Florida, herbivory intensity by M. miamensis was $100 \%$ between 2014 and 2015 in the largest 


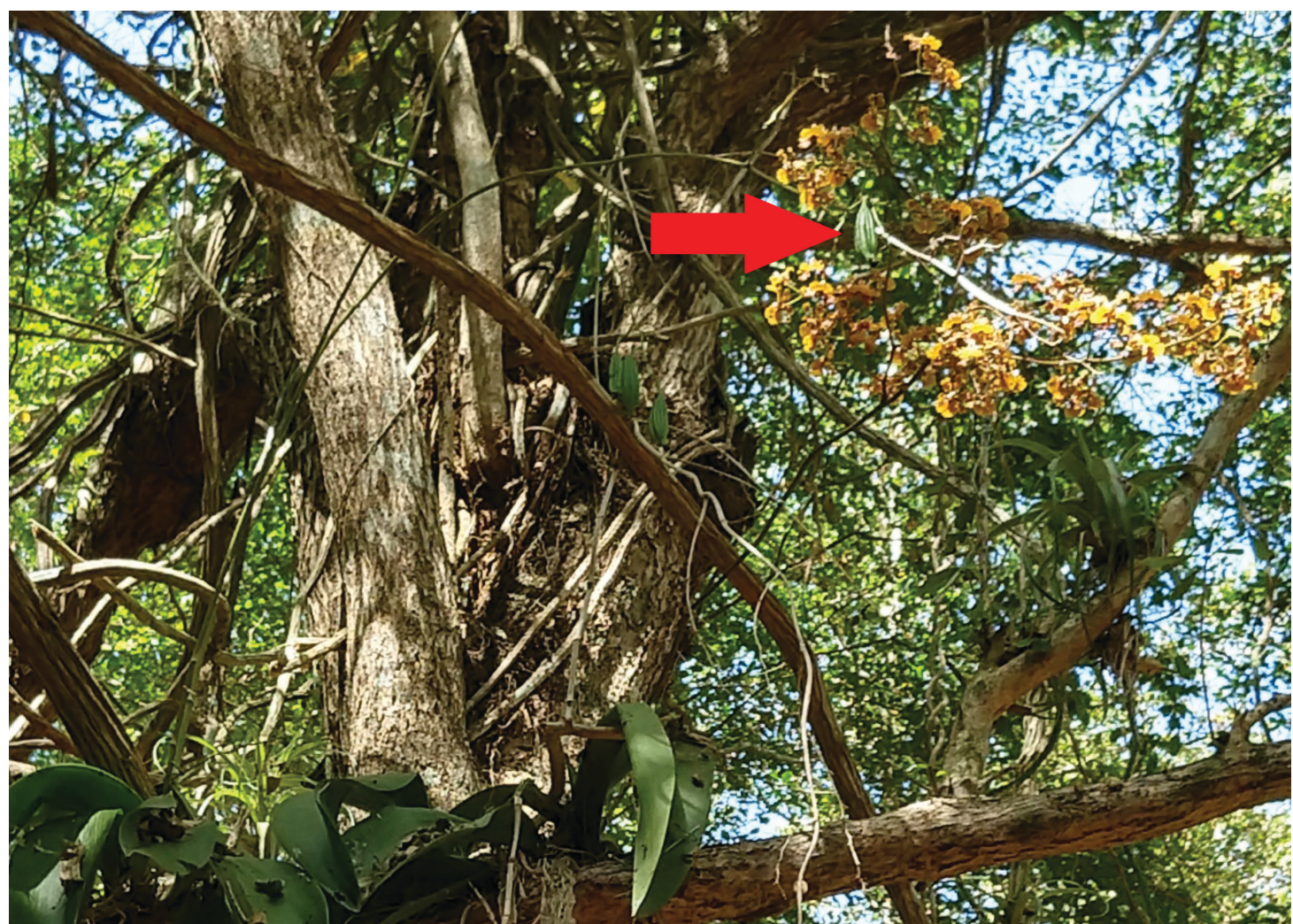

FIGURE 3. An uninfested fruiting inflorescence stalk found in Matanzas Province where no Melanagromyza sp. herbivory was evident.

known T. undulatum population within the Everglades National Park ( $\mathrm{n}=155$ at a $1 \mathrm{~km}$ long transect and a total of 53 inflorescence stalks evaluated), resulting in a very low to none pollination opportunities (loss of flowers) and subsequently, limited fruit/seed production (Gann et al. 2009, Borrero unpubl. 2017). In contrast, only $48 \%$ of flowering plants assessed in Cuba experienced Melanagromyza sp. herbivory between 2016 and 2017. The lower attack rate in Cuba versus that observed in Florida could indicate that different biological and ecological factors exist between populations. Study is on-going in comparing the demography and ecology between the orchid populations in South Florida and Cuba.

ACKNOWLEDGEMENTS. Fieldwork was supported by Florida International University's International Center for Tropical Botany as well as the Tinker Foundation, Judith Evans Parker Travel Scholarship and the Kelly Foundation's Tropical Botany scholarship. We would also like to acknowledge Sonja J. Scheffer of the USDA as well as
James D. Ackerman, Gabriel Francisco Garcés Gonzalez, Leyani Caballero Tihert, Ernesto Mújica, Ester Lidia Santa Cruz Cabrera, Aliesky Gil Carballo, Mario Cisnero, Javier Francisco Ortega, and Jimi Sadle.

\section{Literature Cited}

Ackerman, J. D. (2014). Orchid flora of the Greater Antilles. Memoirs of the New York Botanical Garden 109. New York: The New York Botanical Garden Press.

Gann, G. D., Hines, K. N., Saha, S. \& Bradley, K. A. (2009). Rare plant monitoring and restoration on Long Pine Key, Everglades National Park. Final report, year 5. Miami: The Institute for Regional Conservation. Retrieved from https://regionalconservation.org/ircs/ pdf/LPK_FINAL_REPORT.pdf.

Higgins, W. E. \& Gann, G. D. (2007). The conservation dilemma. Lankesteriana, 7(1-2), 141-146. doi: https:// doi.org/10.15517/lank.v7i1-2.18456

Seavey, R. \& Seavey, J. (2018). Mule ear orchid new fly association. Retrieved from: http://www. seaveyfieldguides.com/mule_ear_orchid_new_fly_ assoc.htm.

LANKESTERIANA 18(3). 2018. (C) Universidad de Costa Rica, 2018. 
Spencer, K. A. (1990). Host specialization in the world Agromyzidae (Diptera). Series Entomologica 45. Dordecht, The Netherlands: Kluwer Academic Publishers. Spencer, K. A. \& Stegmaier, C. E. (1973). Agromyzidae of Florida with a supplement on species from the
Caribbean. Arthropods of Florida, 7, 1-205.

Spencer, K. A. \& Steyskal, G. C. (1986). Manual of the Agromyzidae (Diptera) of the United States. Agriculture Handbook 638. Washington D.C.: U. S. Department of Agriculture, Agricultural Research Service. 